JURNAL ILMIAH KOMPUTER GRAFIS, Vol.14, No.1, Juli 2021, pp. 109 - 127

p-ISSN : 1979-0414(print)

e-ISSN : 2621-6256 (online)

http://journal.stekom.ac.id/index.php/pixel

\title{
Perancangan Forum Diskusi Karyawan Berbasis Web di PT. Rlogic
}

Achmat Mustajib ${ }^{1}$, Sulistianto $\mathrm{SW}^{2}$

${ }^{1}$ Prodi Sistem Informasi STMIK Nusa Mandiri

Jl. Kramat Raya No.18, Jakarta, telp/fax : (021) 31908568, e-mail: ajibxf@gmail.com

${ }^{2}$ Prodi Sistem Informasi STMIK Nusa Mandiri

Jl. Kramat Raya No.18, Jakarta, telp/fax : (021) 31908568, e-mail: sulistianto.sow@nusamanridi.ac.id

\begin{tabular}{|c|c|}
\hline ARTICLE INFO & ABSTRACT \\
\hline $\begin{array}{l}\text { Article history: } \\
\text { Received } 14 \text { mei } 2021 \\
\text { Received in revised form } 14 \text { juni } 2021 \\
\text { Accepted } 15 \text { juni } 2021 \\
\text { Available online July } 2021\end{array}$ & $\begin{array}{l}\text { When a company operates, demands and } \\
\text { responsibilities are attached responsibility for the } \\
\text { company concerned for the local community in } \\
\text { surroundings. Communication in internal } \\
\text { discussions can be said to be more important rather } \\
\text { than external communication, because discussion } \\
\text { must function effectively in achieve its goal of } \\
\text { maintaining relations with all publics within the } \\
\text { discussion. In a In the company there are many } \\
\text { people from various social and different } \\
\text { professionals working for the same goal. It is hoped } \\
\text { that the Employee Discussion Online Forum can } \\
\text { provide benefits and ease of discussion, efficient and } \\
\text { reliable information services updates to employees } \\
\text { and makes it easier for employees to exchange } \\
\text { various ideas and information and can also resolve } \\
\text { conflicts internals. design The development of this } \\
\text { Employee Discussion Online Forum via Internet by } \\
\text { website uses PHP and MySQL applications. }\end{array}$ \\
\hline
\end{tabular}

Keywords: Discussion Forum, Enterprise, internet, PHP, MySQL

\section{Pendahuluan}

Seiring perkembangan teknologi, banyak diskusi yang menggunakan internet sebagai media komunikasi. Forum diskusi online anggota dapat meninggalkan pesan atau mendiskusikan topik tertentu dengan anggota lainnya pada waktu yang sama dengan lokasi yang berbeda tanpa harus datang ke suatu tempat tertentu. Forum online yang berkembang pesat ini merupakan pengembangan dari milis di internet yang sudah ada sejak dulu yang telah dirancang dengan lebih baik dan mudah sebagai tempat untuk berdiskusi secara online.

Diskusi adalah sebuah interaksi komunikasi antara dua orang atau lebih/kelompok. Biasanya komunikasi antara mereka/kelompok tersebut berupa salah satu ilmu atau pengetahuan dasar yang akhirnya akan memberikan rasa pemahaman yang baik dan benar. Diskusi bisa berupa apa saja yang awalnya disebut topik. Dari topik inilah diskusi berkembang dan diperbincangkan yang pada akhirnya akan menghasilkan suatu pemahaman dari topik tersebut, menurut Bosker Sinaga (Volume 18 ISSN 2088-3943). [1] 
Sebuah perusahaan di mana tidak ada berbagi informasi antara dua atau lebih individu, maka pemborosan sumber daya akan sering timbul. Untuk menghindari ini, komunikasi yang efektif di tempat kerja harus didorong untuk keberhasilan perusahaan secara menyeluruh. Perusahaan wajib mendorong korespondensi terbuka dan mudah antara senior dan bawahan. Jika lingkungan kerja ramah di mana bawahan didorong untuk mengkomunikasikan ide-ide mereka kepada manajer mereka mengenai pekerjaan terkait, dan umpan balik mereka diberikan pertimbangan, akan memotivasi karyawan untuk bekerja lebih baik dan membuat mereka merasa dihargai dalam perusahaan. Dengan demikian, komunikasi yang efektif di tempat kerja membantu dalam membangun loyalitas dan kepercayaan yang akhirnya menghasilkan kepuasan kerja yang lebih besar. Komunikasi yang terbuka di tempat kerja dapat membantu mencegah dan menyelesaikan konflik.

Memandang penting Penelitian ini yang mana perusahaan belum mempunyai sebuah web perusahaan yang memudahkan karyawan berbagi Informasi dan ide yang dapat di akses oleh Karyawan PT.RLOGIC melalui internet Dengan adanya website diskusi online ini, diharapkan akan lebih menumbuhkan rasa persatuan dan kekompakkan antara sesama karyawan, serta menjadi tempat yang tepat bagi karyawan untuk dapat mengembangkan kreatifitas, ide-ide, berbagi pengalaman serta bertukar pikiran dalam memecahkan suatu masalah.

\section{Deskripsi Teoritis}

\section{Forum Diskusi}

Pengertian Forum. Menurut KBBI (Kamus Besar Bahasa Indonesia) (2012-2016) forum yaitu :

a. lembaga atau badan/wadah: kita perlu membentuk suatu tempat membicarakan kepentingan bersama.

b. sidang: kedua perkara itu akan dibawa ke depan terbuka.

c. tempat pertemuan untuk bertukar pikiran secara bebas itu sering dimanfaatkan untuk diskusi ilmiah.

d. Forum adalah sebuah wadah yang disediakan untuk berinteraksi bagi para penggunanya dimana para pengguna lebih dimudahkan dalam mencari informasi sesuai dengan kategori-kategori yang diberikan dalam sebuah forum. [2]

\section{Konsep Dasar Pemrograman}

Pada perancangan website diskusi, terutama dalam hal konsep pemrograman penulis menggunkan konsep dasar pemrograman terstruktur. Menurut Sukamto dan Salahuddin (2013:62), konsep dasar pemrograman terstukter adalah konsep atau paradigma atau sudut pandang pemrograman yang membagai-bagi program berdasarkan fungsi-fungsi atau prosedur-prosedur yang dibutuhkan program komputer. [3]

Berikut ini beberapa konsep dasar dalam pemrograman terstruktur, yaitu:

a. Modular

b. Top-Down Progrmmning

c. Progrmming Structure

Dalam pemrograman terstruktur tidak digunakan lagi perintah go-to. Ada tiga bentuk yang digunakan yaitu:

1) Sequence Structure

Bujur sangkar dapat menggambarkan operasi:

a) Input dan Output

b) Operasi aritmatika

c) Operasi pemindahan data dalam memori komputer

Dalam sequence structure tidak diperkenankan penggunaan kotak keputusan.

a) Loop Sructure

b) Selection Structure 


\section{d. Button-Up Programming.}

\section{Personal Home Pages (PHP)}

Menurut Peranginangin (2006:2), "PHP singkatan dari Hypertext Preprocessor yang digunakan sebagai script sever-side dalam pengembangan web yang disisipkan pada dokumen HTML". [4] PHP dapat juga diartikan sebagai sebuah bahasa scripting yang terpasang pada HTML dimana sebagian sintaksnya mirip dengan bahasa C, Java, ASP, dan Perl ditambah beberapa fungsi PHP yang spesifik. PHP dapat diintegrasikan (embedded) ke dalam web server, atau dapat berperan sebagai program CGI yang terpisah. Karakteristik yang paling unggul dan paling kuat dari PHP adalah lapisan intergrasi database (database integration layer). Database yang didukung PHP adalah: Oracle, Adabas-D, Sybase, FilePro, mSQL, Velocis, MySQL, Informix, Solid, dBase, ODBC, Unix dbm dan PostgreSQL.

\section{MySQL}

Menurut pendapat Sukarno (2006:3) "MySQL adalah perangkat lunak untuk sistem manajemen database (database management sistem)". [5] MySQL merupakan software database yang paling populer dikarenakan performa query dari database MySQL dapat dikatakan paling cepat dan bisa dibilang jarang bermasalah.

Menurut Kadir (2008:2) "MySQL merupakan software yang tergolong sebagai DBMS (database management system) yang bersifat open source". Setiap pengguna dapat secara bebas menggunakan MySQL. [6] MySQL adalah sebuah konsep pengoperasian basis data, terutama untuk pemilihan atau seleksi dan pemasukan data yang memungkinkan pengoperasian data dikerjakan dengan mudah secara otomatis.

Suatu sistem basis data (DBMS) dikatakan handal apabila dalam hal cara kerja pengoperasiannya dapat diketahui oleh pengguna maupun program-program aplikasi yang memanfaatkannya. Sebagai peladen basis data, MySQL mendukung operasi basis data transaksional maupun operasi basis data non-transaksional.

Berikut ini beberapa keistimewaan MySQL, diantaranya:

1. Portabilitas.

2. Perangkat Lunak Sumber Terbuka (open source).

3. Multi-User.

4. Memiliki kecepatan yang menkjubkan dan dapat menanagani query sederhana.

5. Ragam Tipe Data.

6. Perintah dan Fungsi.

7. Keamanan.

8. Skalabilitas dan Pembatasan.

9. Konektivitas.

10.Lokalisasi.

11.Antar Muka.

12.Klien dan Peralatan.

13. Struktur Tabel

\section{XАMPP}

Menurut Sidik (2012:71) “XAMPP (X(Qindows/Linux) Apache, MySQL, PHP dan Perl) merupakan paket server web PHP dan database MySQL yang paling populer dikalangan pengembangan web dengan menggunakan php dan mysql sebagai databasenya". [7]

Menurut Madcoms (2011:13) "XAPMPP dan AppServ adalah salah satu paket software web sever yang terdiri dari Apache, MySQL, Php dan Php MyAdmin". [8]

Dari pendapat diatas maka dapat disimpulkan bahwa XAMPP adalah aplikasi web server yang mengggabungkan PHP, Web server Apache dan database MySQL.

Peralatan Pendukung Sistem 
1. UML (unfied Modelling Language)

Menurut Sukamto dan Shalahuddin (2013:133) "UML (unified Modelling Language) adalah salah satu standar bahasa yang banyak digunakan di dunia industri untuk mendefinisikan requirement, membuat analisis \& desain, serta menggambarkan arsitektur dalam pemrograman berorientasi objek." [9]

UML muncul karena adanya kebutuhan pemodelan visual untuk menspesifikasikan, menggambarkan, membangun, dan dokumentasi dari sistem perangkat lunak. UML merupakan bahasa visual untuk melakukan pemodelan. Jadi pengguna UML tidak terbatas pada metodologi tertentu, meskipun pada kenyataanya UML paling banyak digunakan pada metodologi berorientasi objek.UML (unified Modelling Language) untuk pemrograman terstruktur mendefinisikan diagram-diagram sebagai berikut :

a. Use Case Diagram

Menurut Sukamto dan Shalahuddin (2013:155) "Use case atau diagram use cas merupakan pemodelan untuk melakukan (behavior) sistem informasi yang akan dibuat. Secara kasar, use case digunakan untuk mengetahui fungsi apa saja yang ada di dalam sebuah system informasi dan siapa saja yang berhak menggunakan fungsi-fungsi itu". [10]

b. Activity Diagram

Menurut Sukamto dan Shalahuddin (2013:161) "Diagram aktivitas atau activity diagram menggambarkan workflow (aliran kerja) atau aktivitas dari sebuah sistem atau proses bisnis atau menu yang ada pada perangkat lunak. Yang perlu diperhatikan disini adalah bahwa diagram aktivitas menggambarkan aktivitas sistem bukan apa yang dilakukan aktor, jadi aktivitas yang dapat dilakukan oleh sistem". [11]

c. Component Diagram

Menurut Sukamto dan Shalahuddin (2013:148) "Diagram komponen atau component diagram dibuat untuk menunjukan organisai dan ketergantungan diantara kumpulan komponen dalam sebuah sistem. Diagram komponen fokus pada komponen sistem yang dibutuhkan dan ada di dalam sistem". [12]

d. Diagram Deployment (Deployment Diagram)

Menurut Sukamto dan Shalahuddin (2013:154) "Diagram deployment atau deployment diagram menunjukan konfigurasi komponen dan proses eksekusi aplikasi”. [13]

2. ERD (Entity Relationship Diagram)

Menurut Sukamto dan Shalahuddin (2014:50) "Pemodelan awal basis data yang paling banyak digunakan adalah menggunakan Entity Relationship Diagram (ERD). ERD dikembangakan berdasarkan teori himpunan dalam bidang matematika. ERD digunakan untuk pemodelan basis data relasional."ERD biasanya memiliki hubungan binary (satu relasi menghubungkan dua buah entitas). Beberapa metode perancangan ERD menoleransi hubungan relasi ternary (satu ralasi menghubungkan tiga buah relasi) atau $\mathrm{N}$-ary (satu relasi menghubungkan banyak entitas), tapi banyak metode perancangan ERD yang tidak mengizinkan hubungan ternary atau $N$-ary. [14]

\section{Javascript}

Javascript menurut (Sunyoto,2007:17) adalah bahasa scripting yang popular di internet dan dapat bekerja di sebagian besar browser populer seperti Internet Explorer (IE), Mozilla Firefox, Netscape dan Opera. [15] Kode Javascript dapat disisipkan dalam halaman web menggunakan tag SCRIPT,Beberapa hal tentang Javascript :

1. Javascript didesain untuk menambah interaktif suatu web.

2. Javascript merupakan sebuah bahasa scripting.

3. Bahasa scripting merupakan bahasa pemograman yang ringan.

4. Javascript berisi baris kode yang dijalankan di komputer (web browser).

5. Javascript biasanya disisipkan (embedded) dalam halaman HTML.

6. Javascript adalah bahasa interpreter (yang berarti skrip dieksekusi tanpa proses

\section{CSS (Cascading Style Sheet)}


Menurut Didik Setiawan (2017:121) "CSS(Cascading Style Sheet) adalah aturan dalam pembuatan webuntuk mengatur komponen yang ada sehingga akan lebih terstruktur. Dengan CSS dapat mengatur semua komponen yang ada misalnya warna, posisi komponen, jarak antar komponen dan lainnya. [16] CSS adalah bahasa style sheet yang digunakan untuk mengatur tampilan dokumen. Dengan adanya CSS memungkinkan kita untuk menampilkan halaman yang sama dengan format yang berbeda. CSS merupakan aturan untuk mengendalikan beberapa komponen dalam sebuah web sehingga akan lebih terstruktur dan seragam, namun CSS bukan merupakan bahasa pemprograman.

Pada umumnya CSS dipakai untuk memformat tampilan halaman web yang dibuat dengan bahasa HTML dan XHTMLCSS berguna untuk mengatur style, misalnya heading, subbab, bodytext, footer, images dan style lainnya untuk dapat digunakan bersama-sama dalam beberapa berkas dan dapat mengendalikan ukuran, gambar, warna bagian tubuh pada teks, warna tabel, ukuran border, spasi antar paragraf, spasi antar teks, margin kiri, kanan, atas, bawah dan parameter lainnya

\section{Pengujian Software}

Metode pengujian adalah cara atau teknik untuk menguji perangkatlunakmempunyai mekanisme untuk menentukan data uji yang dapat menguji perangkat lunak secara lengkap dan mempunyai kemungkinan tinggi untuk menemukan kesalahan.

Menurut Khan, dalam Mustqbal, Dkk (2015:33) "Ada beberapa cara pengujian perangkat lunak, antara lain:

1. Pengujian White Box.

2. Pengujian Black Box." [17]

Menurut Mustqbal, Dkk (2015:34) "Black Box Testing berfokus pada spesifikasi fungsional dari perangkat lunak" [18] Tester dapat mendefinisikan kumpulan kondisi input dan melakukan pengetesan pada spesifikasi fungsional program. Black Box Testing bukanlah solusi alternatif dari White Box Testing tapi lebih merupakan pelengkap untuk menguji hal-hal yang tidak dicakup oleh White Box Testing. Black Box Testing cenderung untuk menemukan hal-hal berikut:

1. Fungsi yang tidak benar atau tidak ada.

2. Kesalahan antarmuka (interface errors).

3. Kesalahan pada struktur data dan akses basis data.

4. Kesalahan performansi (performance errors).

\section{Penelitian Terkait}

Berikut ini penelitian terdahulu yang berhubungan dengan skripsi ini antara lain :

1. Penelitian yang di lakukan oleh Binsar Tampahan Siagian dan Dana Indra Sensuse (Volume 6, ISSN 1412-8896) yang berjudul "Pemetaan dan analisis knowledge sharing pada situs forum komunitas online kaskus" [19] dalam penelitian ini akan digunakan metode Social Network Analysis (SNA) yang paling tepat dalam mengukur model/pola knowledge sharing tersebut. Obyek penelitian ini adalah suatu forum terbesar di Indonesia, yaitu forum Kaskus khususnya pada threads Programmer Forum yang berada di sub forum Computer Stuff. Visualisasi dan analisis dari pola interaksi di dalam forum tersebut akan dibahas dalam penelitian ini. Hasil dari penelitian ini adalah didapatkannya suatu model knowledge sharing dalam forum tersebut, yang sangat berguna untuk menilai forum Kaskus, khususnya pada knowledge sharing di dalamnya.

2. Penelitian yang dilakukan oleh Aries Dwi Indriyanti dan Revaldo Pratama pada tahun 2015 dengan judul" Perancangan dan Pembuatan Forum Makanan Berbasis Web". [20] Pada penelitian ini, penulis membuat aplikasi forum makanan menggunakan web. Dengan menggunakan web dapat mempermudah para member dalam bertukar berbagai 
menu dan resep makanan.Dikarenakan sharing menu makanan dapat dilakukan dimana saja dan kapan saja tanpa harus bertatap muka dengan sesama member. Dengan menggunakan web, admin akan lebih mudah dalam mengakses data para member tanpa harus ketemu para member. Hasil dari penelitian ini adalah sebuah perancangan forum makanan berbasis web yang mengimplementasikan teknik pemprograman sebagai tempat sharing para member atau pecinta kuliner.

3. Penelitian dari Prita Widiastuti pada tahun 2012 dengan judul "Pemanfaatan forum offline oleh komunitas on-line Pengusaha Muda Jogja (PMJ)“. [21] Hasil penelitian menunjukkan bahwa banyak sekali manfaat dari forum off-line oleh komunitas PMJ.Pemanfaatan tersebut terbagi menjadi 3(tiga) lingkup, yaitu kopi darat, sharing, dan komersil. Pertama, kopi darat dimanfaatkan anggota PMJ sebagai wadah atau tempat untuk berkumpul bersama sesame pengusaha. Mereka dapat sharing pengalaman usaha antar anggota PMJ, mendapat rekan bisnis, dan menambah link atau jaringan.Sehingga terjalin kerjasama yang saling menguntungkan.Anggota dapat meningkatkan konsumen dan keuntungan, dan menganggap kopi darat lebih nyaman untuk dilakukan.Selain itu kopi darat juga dapat menambah kesibukan dan sebagai sarana hiburan.Kedua, manfaat sharing adalah untuk dapat memenuhi kebutuhan yang diinginkan oleh para anggotanya dan memberi motivasi kepada para anggota untuk menjadi pengusaha yang sukses.Ketiga, komersil mempunyai manfaat yaitu pada jual beli forum off-line dianggap lebih aman dan mantab.Dapat meningkatkan keuntungan dan meningkatkan kepercayaan konsumen maupun dengan sesama anggota dalam hal kerjasama.Selain itu juga dapat menambah konsumen dan menaikkan penjualan usaha mereka.

4. Penelitian dari Agus Putranto pada tahun 2012 dengan judul "Perancangan Forum Diskusi Mobile Learning". [22] Tujuan penelitian ini ialah melakukan analisis kebutuhan dan kemudian menentukan rancangan pada forum diskusi M-Learning pada Binus Online Learning agar dapat mudah digunakan dan cepat dalam pengaksesannya. Dalam penelitian ini digunakan metode pengumpulan data (dengan melakukan survei), dan metode analisis yang terbagi atas studi kepustakaan, dan analisis sistem berjalan. Sedangkan perancangan menggunakan Rich Picture dan rancangan layar. Hasil yang dicapai ialah fitur-fitur forum diskusi Mobile Learning.

\section{Metode Penelitian}

Metode yang di gunakan dalam pengembangan sistem adalah metode Waterfall. Metode ini merupakan metode yang sering digunakan oleh penganalisa sistem pada umumnya.

\section{Analisa Kebutuhan system. \\ Desain}

a. Mengidentifikasi adanya permasalahan yang signifikan untuk dipecahkan melalui metode deskriptif.

b. Membatasi dan merumuskan permasalahan secara jelas.

c. Melakukan tujuan dan manfaat penelitian.

d. Melakukan studi pusaka yang berkaitan dengan permasalahan.

e. Menentukan kerangka berfikir, dan pertanyaan penelitian dan atau hipotesis penelitian.

3. Code Generation.

4. Testing.

5. Support.

\section{Analisa Kebutuhan Software}


Menurut (Pressman, 2010) Analisis kebutuhan merupakan bagian dari proses kebutuhan perangkat lunak yang berperan menjembatani jurang yang sering terjadi antara level rekayasak ebutuhan dan perancangan perangkat lunak. [23]

\section{Tahap Analisis}

Ruang diskusi berbasis web terdiri dari admin dan User, berikut spesifikasi kebutuhan dari web tersebut:

a. Halaman Admin

1) Admin dapat login Admin.

2) Admin dapat mengelola beranda.

3) Admin dapat mengelola Tentang web

4) Admin dapat mengelola User/karyawan.

5) Admin dapat mengelola Forum Diskusi.

6) Admin dapat Logout.

b. Halaman User

1) User dapat Registrasi akun sendiri

2) User dapat Mengelola akun sendiri

3) User dapat melihat beranda.

4) User dapat melihat Tentang web

5) User dapat membuat topik baru

6) User dapat berdiskusi di halaman Forum.

7) User dapat Logout

\section{Use Case Diagram}

a. Halaman Admin

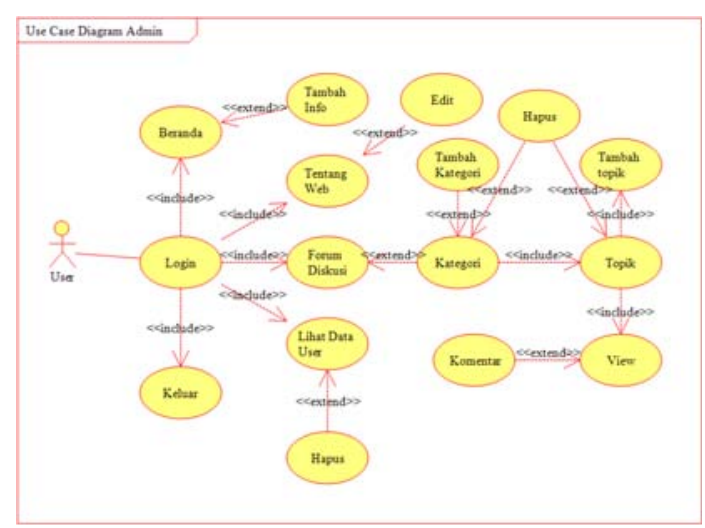

Gambar. 1. Usecase Diagram Adminitrator

b. Halaman User 


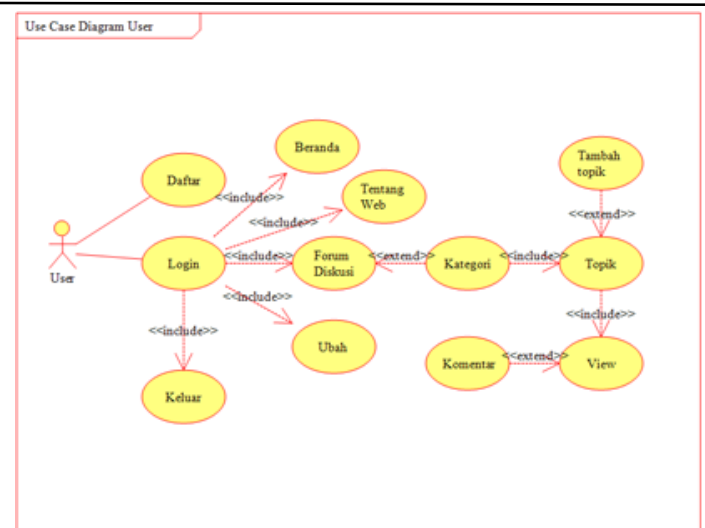

Gambar 2. Usecase Diagram User

\section{Activity Diagram}

a. Halaman Admin

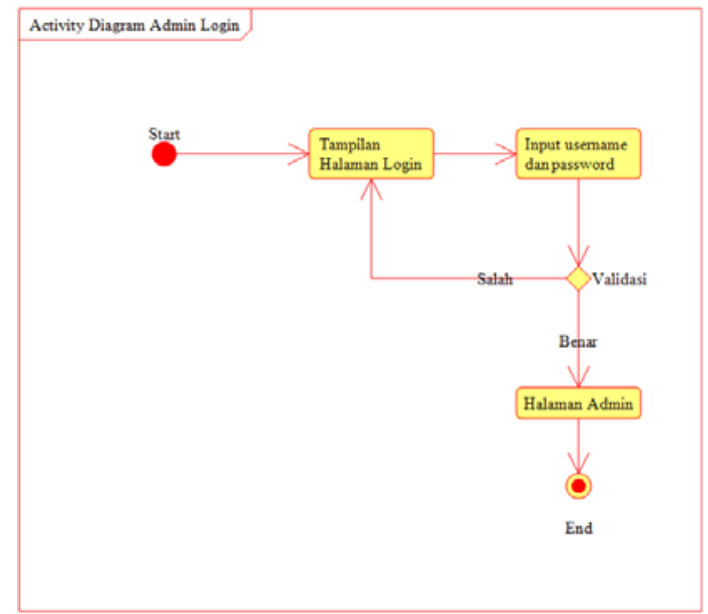

Gambar 3. Activity Diagram Admin Login

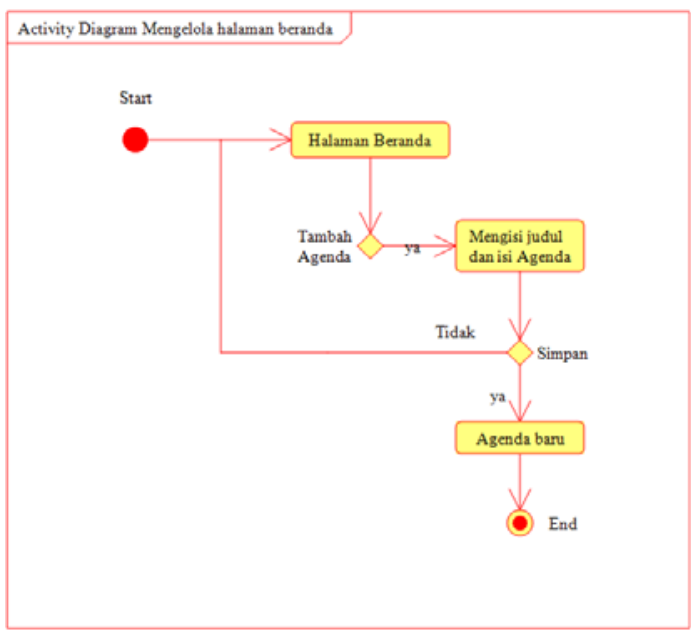

Gambar 4. Activity Diagram Mengelola Halaman Beranda 


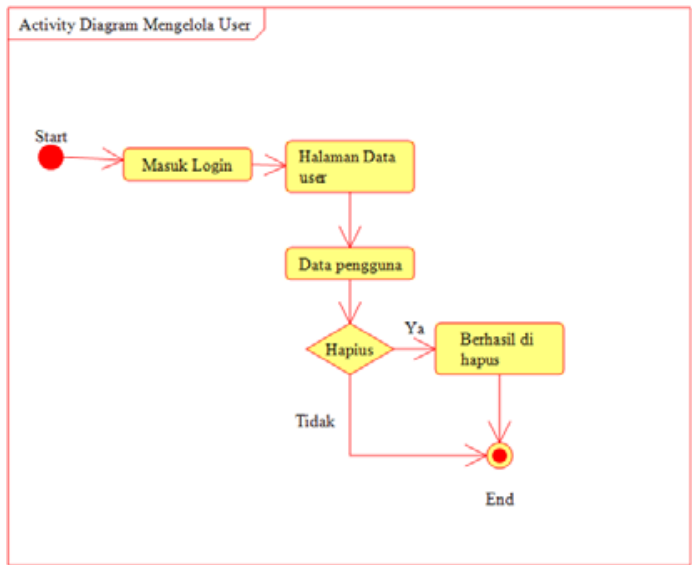

Gambar 5. Activity Diagram Mengelola Data User

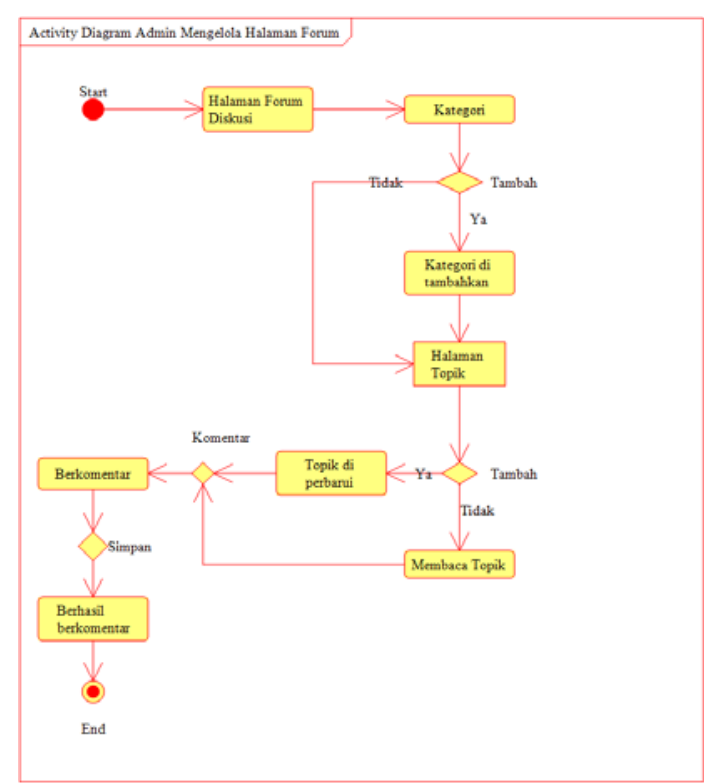

Gambar 6. Activity Diagram Admin Mengelola Halaman Forum

b. Halaman User 


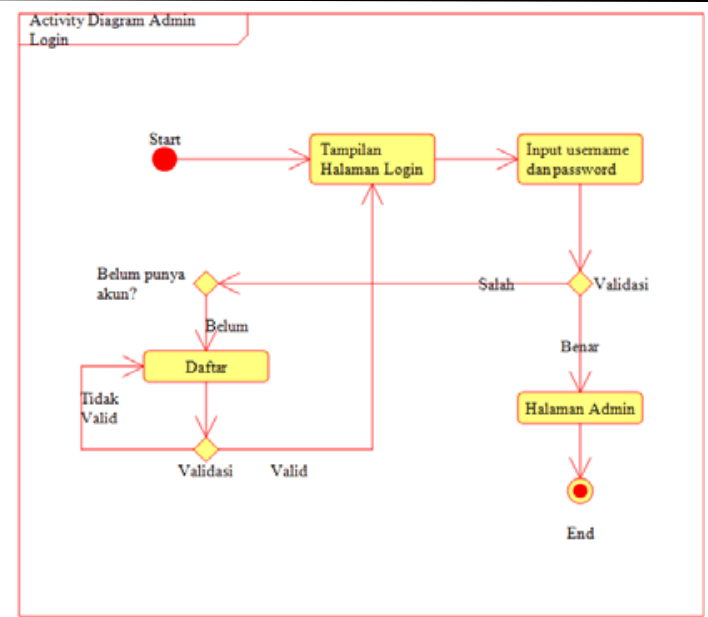

Gambar 7. Activity Diagram User Registrasi dan User

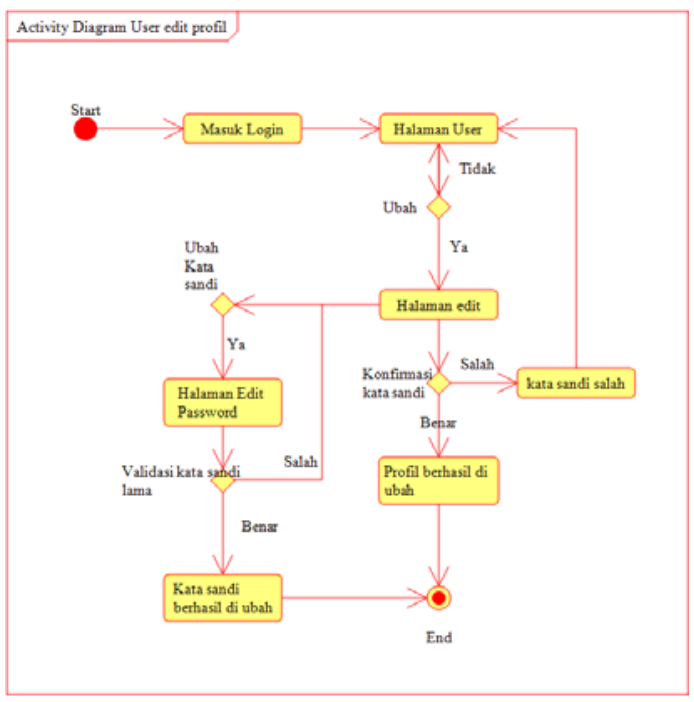

Gambar 8. Activity Dagram User Edit Profil 


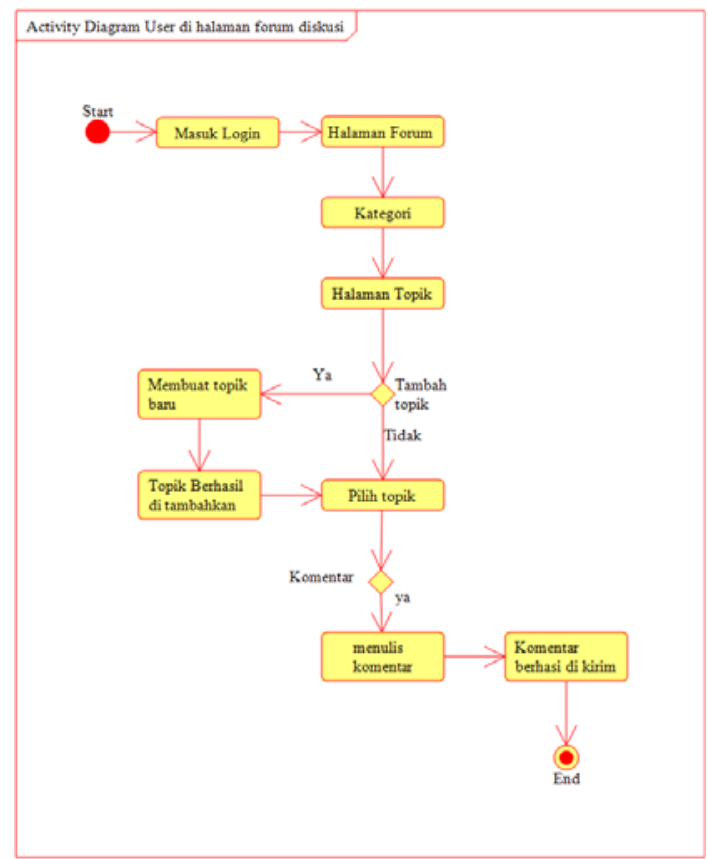

Gambar 9. Activity Diagram User di Halaman Forum Diskusi

\section{Database}

Menggambarkan hubungan antar table yang di buat beserta relasi antar table dalam penggambaranya penulis menggunakan Entity Relation Diagram (ERD). Karena menggambarkannya dengan ER-Diagram maka penulis juga membuat spesifikasi filenya.

1. Entity Relation Diagram

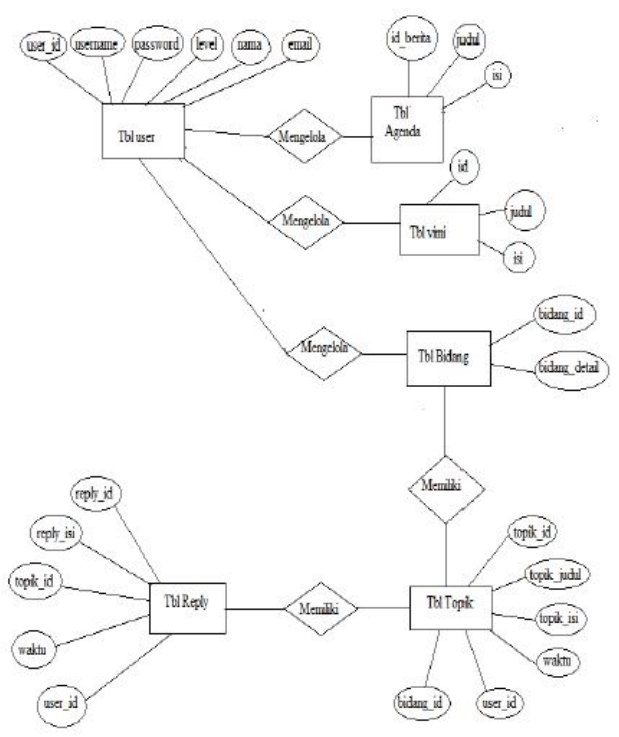

Gambar 10. ERD Forum Diskusi Web

\section{Logical Local Structure}




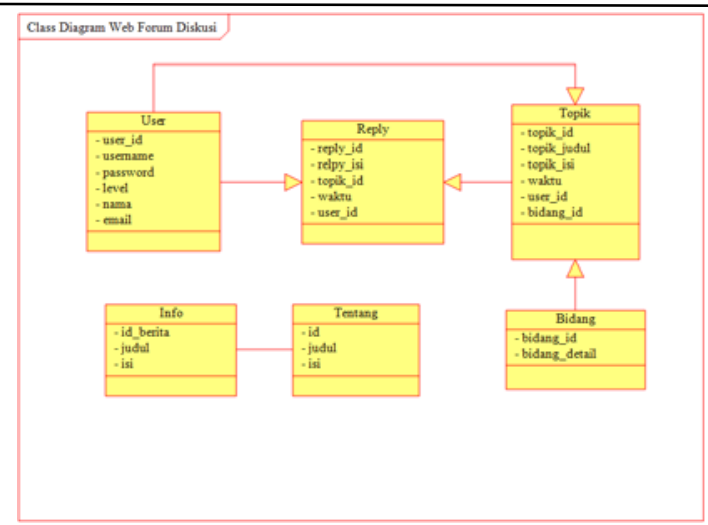

Gambar 11. LRS Forum Diskusi Web

\section{Spesifikasi File}

Merupakan kumpulan item data yang di atur di dalam suatu record di mana item-item data tersebut di manipulasi untuk memproses data tertentu, dalam perancangan program ini disebut Forum.

a. Spesifikasi File Tabel Bidang

Tabel 1. Spesifikasi File Table User

\begin{tabular}{|c|c|c|c|c|c|}
\hline No & Element Data & Nama Field & Type & Size & Keterangan \\
\hline 1 & Id & User_id & Int & 10 & Primary Key \\
\hline 2 & User Name & Inser Name & Varchar & 50 & \\
\hline 3 & Password & Password & Varchar & - & \\
\hline 4 & Level & Level & Set (admin.guest) & 50 & \\
\hline 5 & Nama & Nama & Varchar & 50 & \\
\hline 6 & Email & Email & Varchar & 50 & Foreign Key \\
\hline
\end{tabular}

b. Spesifikasi File Tabel Agenda

Tabel 2. Spesifikasi File Table Agenda

\begin{tabular}{|l|l|l|l|l|l|}
\hline No & Element Data & Nama Field & Type & Size & Keterangan \\
\hline 1 & Id Berita & Berita_id & Int & 1 & Primary Key \\
\hline 2 & Judul & Judul & Varchar & 50 & \\
\hline 3 & Isi & Isi & Varchar & 50 & Foreign Key \\
\hline
\end{tabular}

c. Spesifikasi File Tabel Bidang

Tabel 3. Spesifikasi File Table Bidang

\begin{tabular}{|l|l|l|l|l|l|}
\hline No & Element Data & Nama Field & Type & Size & Keterangan \\
\hline 1 & Id Bidang & Bidang_id & Int & 1 & Primary Key \\
\hline 2 & Detail Bidang & Bidang_detail & Varchar & Text & Foreign Key \\
\hline
\end{tabular}

d. Spesifikasi File Tabel Reply 
Tabel 4. Spesifikasi File Table Reply

\begin{tabular}{|l|l|l|l|l|l|}
\hline No & Element Data & Nama Field & Type & Size & Keterangan \\
\hline 1 & Id Reply & Reply_id & Int & 11 & Primary Key \\
\hline 2 & Isi Reply & Isi_id & Varchar & - & \\
\hline 3 & Id Topik & Topic_id & Varchar & 50 & \\
\hline 4 & Waktu & Waktu & Varchar & 50 & \\
\hline 5 & Id User & User_id & Varchar & 10 & Foreign Key \\
\hline
\end{tabular}

e. Spesifikasi File Tabel Reply

Tabel 5. Spesifikasi File Table Topik

\begin{tabular}{|l|l|l|l|l|l|}
\hline No & Element Data & Nama Field & Type & Size & Keterangan \\
\hline 1 & Id Topik & TopiReply_id & Int & 10 & Primary Key \\
\hline 2 & Judul Topik & Isi_id & Varchar & 200 & \\
\hline 3 & Isi Topik & Topic_id & Text & - & \\
\hline 4 & Waktu & Waktu & Varchar & 50 & \\
\hline 5 & Id User & User_id & Varchar & 10 & \\
\hline 6 & Id Bidang & Bidang_id & Varchar & 10 & Foreign Key \\
\hline
\end{tabular}

f. Spesifikasi File Tabel Tentang WebReply

Tabel 6. Spesifikasi File Table Vimi

\begin{tabular}{|l|l|l|l|l|l|}
\hline No & Element Data & Nama Field & Type & Size & Keterangan \\
\hline 1 & Id Vimi & Id & Int & 1 & Primary Key \\
\hline 2 & Judul & Judul & Varchar & 50 & \\
\hline 3 & Isi & Isi & Varchar & 50 & Foregin Key \\
\hline
\end{tabular}

\section{Software Architecture}

1. Class Diagram

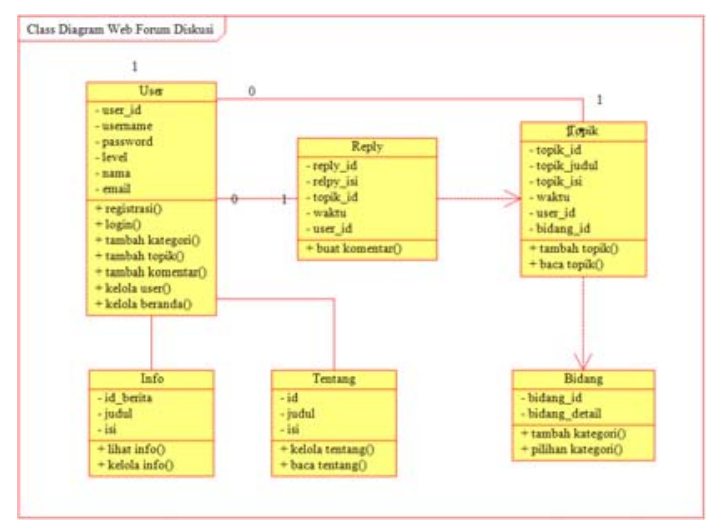

Gambar 12. Class Diagram Web Forum Diskusi

\section{Sequence Diagram}

1. Sequence Diagram User Registrasi 


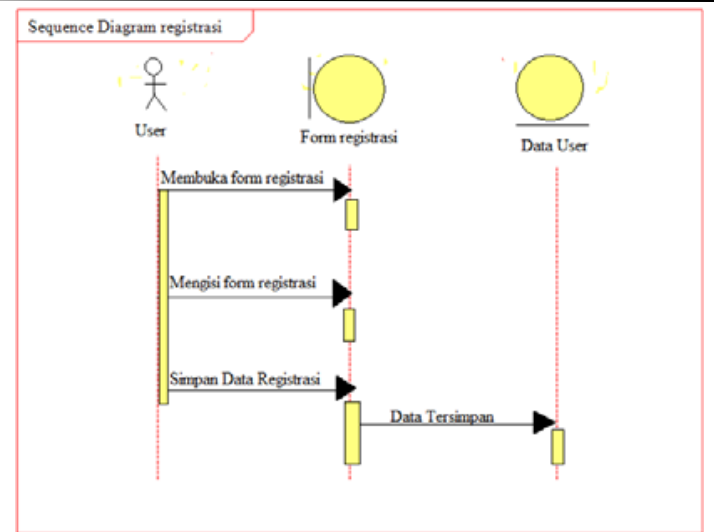

Gambar 13. Sequence Diagram User Registrasi

2. Sequence Diagram Login

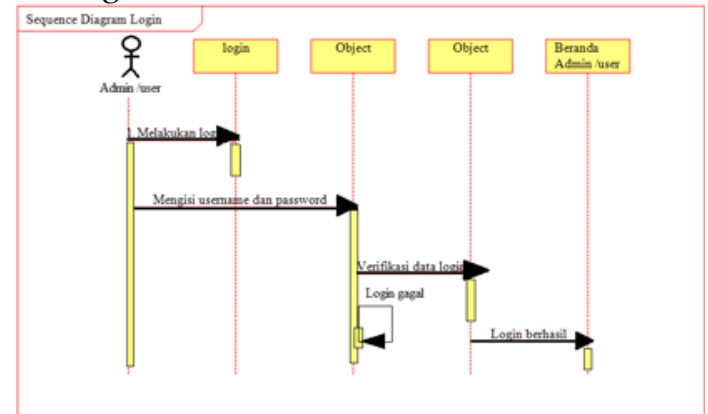

Gambar 14. Sequence Diagram Login (Admin dan User)

3. Sequence Diagram User Diskusi Forum

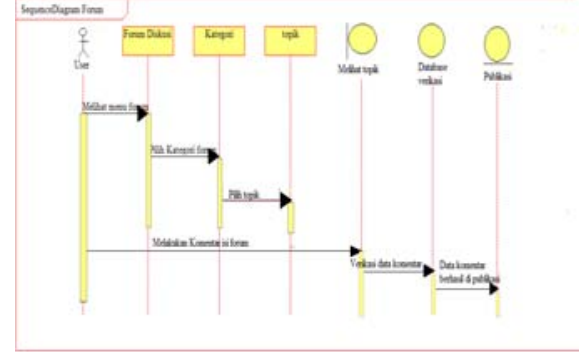

Gambar 15. Sequence Diagram User Diskusi Forum 


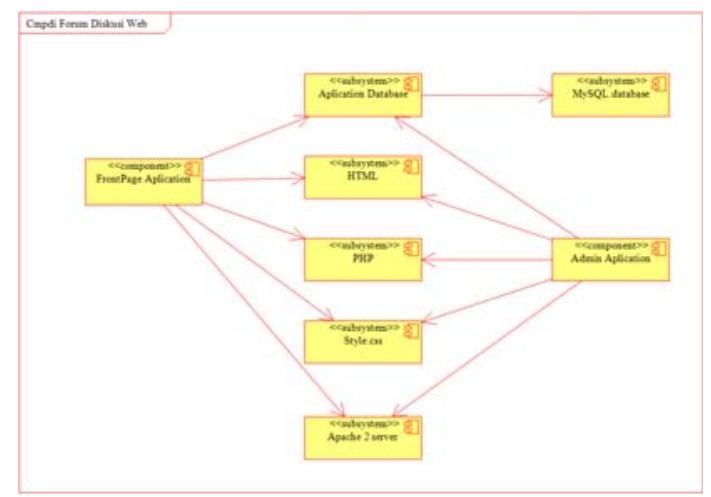

Gambar 16. Component Diagram Web Dsikusi Forum

\section{Deployment Diagram}

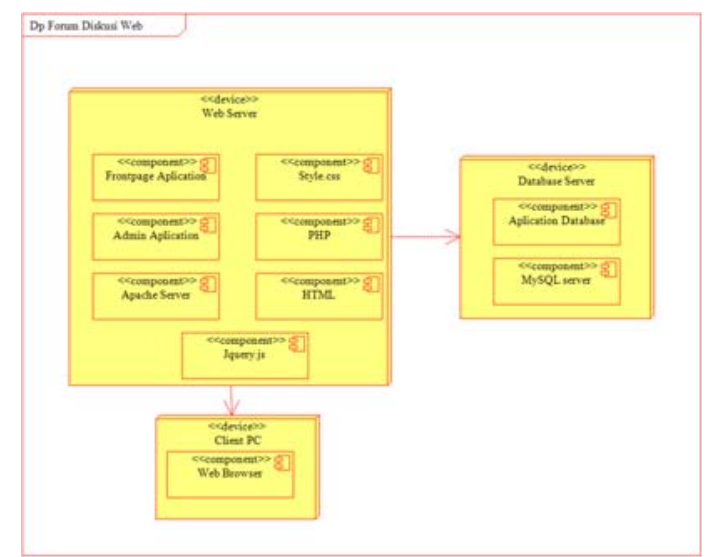

Gambar 17. Deployment Diagram Web Dsikusi Forum

\section{User Interface}

1. Halaman Login

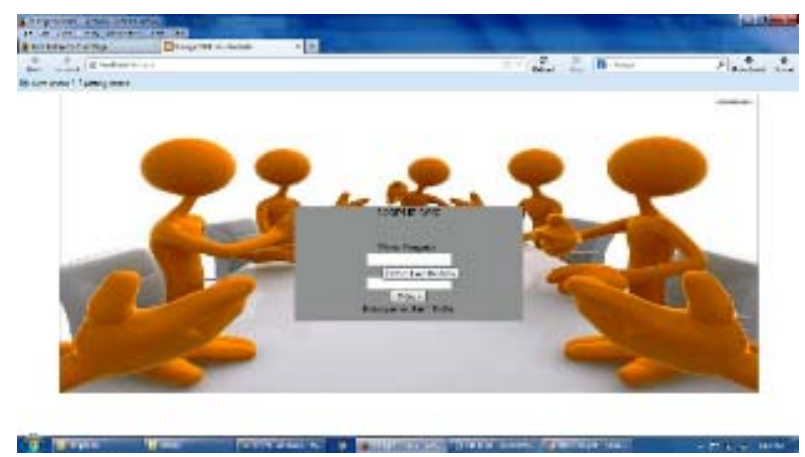

Gambar 18. Tampilan Halam Login (Admin dan User)

2. Halaman Beranda User 


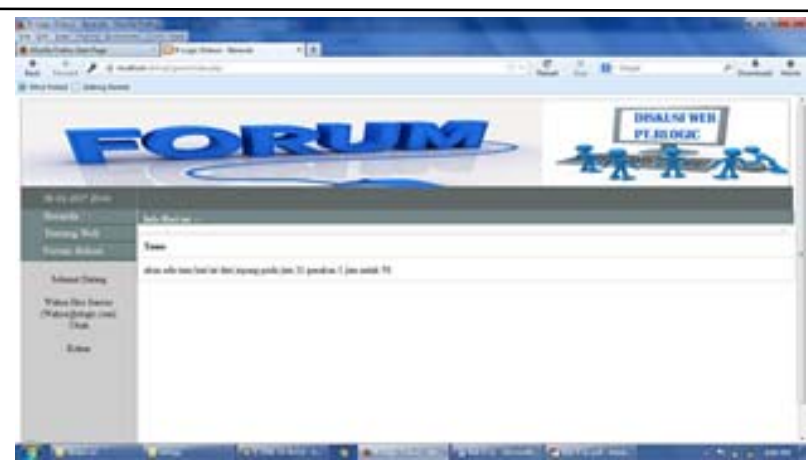

Gambar 19. Halaman Beranda User

3. Halaman Admin Forum Diskusi

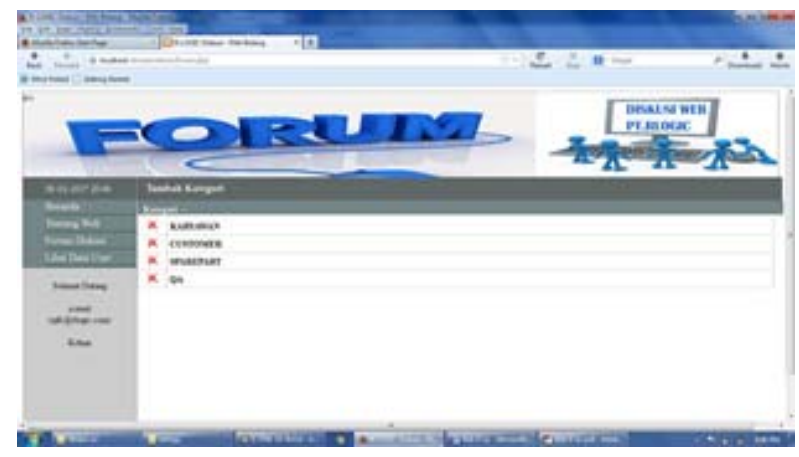

Gambar 20. Halaman Admin Forum Diskusi

4. Halaman Data User

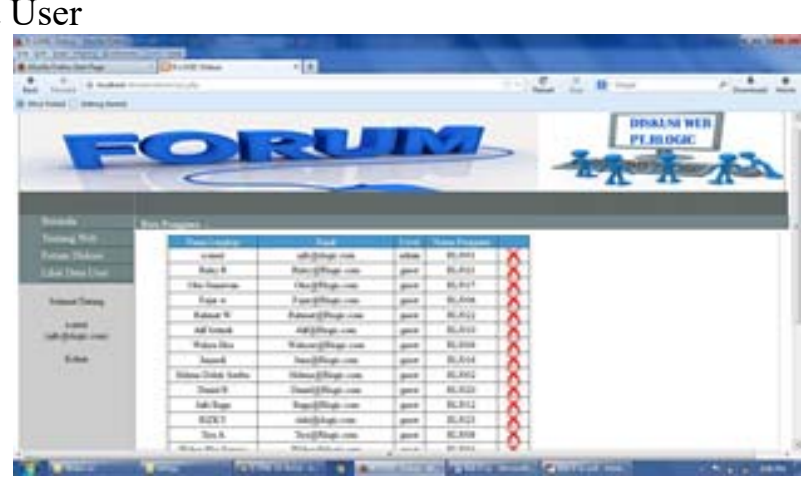

Gambar 21. Halaman Data User

\section{Testing}

Pembahasan mengenai pengujian sistem yang dibuat dengan menggunakan black box testing untuk pengujian proses input dan output pada Web Forum Diskusi di PT. Rlogic sebagai berikut:

Tabel 7. Hasil Penujian Black Box dari Login

\begin{tabular}{|l|l|l|l|l|l|}
\hline No & Skenarion Pengujian & Test Case & $\begin{array}{l}\text { Hasil yang } \\
\text { iharapkan }\end{array}$ & $\begin{array}{l}\text { Hasil } \\
\text { Pengujian }\end{array}$ & Kesimpulan \\
\hline
\end{tabular}




\begin{tabular}{|c|c|c|c|c|c|}
\hline 1 & $\begin{array}{l}\text { Mengosongkan } \\
\text { semua isian data } \\
\text { login pada login } \\
\text { User, lalu klik } \\
\text { tombol "Login" }\end{array}$ & $\begin{array}{l}\text { User_id } \\
\text { (kosong) } \\
\text { Password } \\
\text { (kosong) }\end{array}$ & $\begin{array}{l}\text { Sistem akan } \\
\text { menolak } \\
\text { akses } \\
\text { login dan } \\
\text { menampilkan } \\
\text { pesan "Nama } \\
\text { pengguna } \\
\text { atau } \\
\text { password } \\
\text { salah" }\end{array}$ & $\begin{array}{l}\text { Sesuai } \\
\text { harapan }\end{array}$ & Valid \\
\hline 2 & $\begin{array}{l}\text { Hanya mengisi } \\
\text { data User id dan } \\
\text { mengosongkan } \\
\text { password lalu } \\
\text { klik } \\
\text { tombol "Login" }\end{array}$ & $\begin{array}{l}\text { User_id } \\
\text { (Ajib) } \\
\text { Password } \\
\text { (kosong) }\end{array}$ & $\begin{array}{l}\text { Sistem akan } \\
\text { menolak } \\
\text { akses } \\
\text { login dan } \\
\text { menampilkan } \\
\text { Pesan } \\
\text { "Password } \\
\text { tidak boleh } \\
\text { kosong" }\end{array}$ & $\begin{array}{l}\text { Sesuai } \\
\text { Harapan }\end{array}$ & Valid \\
\hline 3 & $\begin{array}{l}\text { Hanya mengisi } \\
\text { data password } \\
\text { dan } \\
\text { mengosongkan } \\
\text { User id lalu klik } \\
\text { tombol'Login" }\end{array}$ & $\begin{array}{l}\text { Username } \\
\text { (Kosong) } \\
\text { Password } \\
(12345)\end{array}$ & $\begin{array}{l}\text { Sistem akan } \\
\text { menolak } \\
\text { akses } \\
\text { login dan } \\
\text { menampilkan } \\
\text { Pesan"User } \\
\text { id } \\
\text { tidak boleh } \\
\text { kosong" }\end{array}$ & $\begin{array}{l}\text { Sesuai } \\
\text { Harapan }\end{array}$ & Valid \\
\hline 4. & $\begin{array}{l}\text { Mengisi data } \\
\text { User id dan } \\
\text { Password } \\
\text { dengan benar } \\
\text { lalu klik } \\
\text { tombol'Login" }\end{array}$ & $\begin{array}{l}\text { Username } \\
\text { (Ajib) } \\
\text { Password } \\
(12345)\end{array}$ & $\begin{array}{l}\text { Sistem akan } \\
\text { menerima } \\
\text { akses } \\
\text { Login dan } \\
\text { kemudian } \\
\text { masuk ke } \\
\text { Halaman } \\
\text { beranda } \\
\text { Admin } \\
\text { maupun User }\end{array}$ & $\begin{array}{l}\text { Sesuai } \\
\text { Harapan }\end{array}$ & Valid \\
\hline
\end{tabular}

\section{Kesimpulan}

Dari Perancangan pembuatan Forum Diskusi Karyawan Berbasis web pada PT. Rlogic Indonesia maka dapat ditarik kesimpulan sebagai berikut :

1. Terbangunnya website Forum Diskusi pada PT. Rlogic yang bersifat internet menggunakan bahasa pemrograman PHP dan database MySQL sesuai dengan 
perencanaan serta dengan tersedianya website forum ini dapat membantu interaksi dan komunikasi atau permasalahan baik dalam bidang produksi maupun sosial yang terjadi.

2. Dengan adanya Forum Diskusi Online di PT. Rlogic, memudahkan para karyawan untuk saling berbagi ilmu pengetahuan yang dimiliki dan karyawan lebih mudah mendapatkan informasi tentang pengumuman yang berjalan di sekitar lingkungan Perusahaan karena tersedianya berita terkini/Agenda/acara yang merupakan pengumuman seputar Perusahaan.

3. Aplikasi website Forum Diskusi dapat mempererat rasa kebersamaan antar karyawan maupun manager serta menumbuhkan rasa saling berbagi antar sesama karyawan, selain itu semua peserta diskusi bisa melakukannya walau ditempat berbeda, baik di kantor pusat maupun cabang dan hasil diskusi maupun informasi bisa langsung dilihat kembali di web Forum Diskusi.

\section{Daftar Pustaka}

[1] Bosker Sinaga, Perancangan dan Pembuatan Sstem Informasi Forum Diskusi Mahasiswa/i Berbasis Web di STMIK Pelita Nusantara Medan, Jurnal Mantik Penusa, Vol. 18 No. 2, Published: 2015-12-02. Hal. 58-63.

[2] (KBBI), Kamus Besar Bahasa Indonesia. Arti Kata Televisi. 2012-2016. http://kbbi.web.id/televisi

[3] Sukamto, \& Shalahuddin. (2013). Analisa dan Desain Sistem Informasi. Yogyakarta: Andi Offset.

[4] Peranginangin, Kasiman. 2006. Aplikasi Web Dengan PHP Dan MySql. Yogyakarta : Andi Offset.

[5] Sukarno, Mohamad. 2006. Membangun Website Dinamis Interaktif dengan PHP MySql (Windows \& Linux). Jakarta : Eska Media.

[6] Khadir, Abdul. 2008. Tuntutan Praktis Belajar Database Menggunakan MySql. Yogyakarta : Andi Offset.

[7] Sidik, B. (2012). Pemrograman Web dengan PHP. Solo. Santika Kencana.

[8] Madcoms. 2011. Aplikasi Web Database dengan Dreamweaver dan PHP-MySQL. Yogyakarta: CV Andi Offset.

[9] Sukamto, R. A. dan Shalahuddin, M. 2013. Rekayasa Perangkat Lunak Terstuktur dan Berorientasi ObjekBandung: Informatika, hal.. 133.

[10] idem, hal. 155.

[11] idem, hal. 161.

[12] idem, hal. 148.

[13] idem, hal. 154.

[14] Sukamto, R. A. dan Shalahuddin, M. 2014. Rekayasa Perangkat Lunak Terstuktur dan Berorientasi Objek Bandung: Informatika.

[15] Sunyoto, Andi. 2007. Ajax Membangun Web dengan Teknologi Asynchronouse Javascript dan XML. Yogyakarta: Andi Offset.

[16] Setiawan, Didik. 2017. Buku Sakti Pemrograman Web : HTML, CSS, PHP, MySQL \& JavaScript. Yogyakarta : PT. ANAK HEBAT INDONESIA.

[17] Mustaqbal, M.S.M., Firdaus, R.F.F., dan Rahmadi, H.R. 2015. Pengujian Aplikasi Menggunakan Black Box Testing Boundary Value Analysis (Studi Kasus Aplikasi Prediksi Kelulusan SNMPTN). Jurnal Ilmiah Teknologi Terapan (JITTER), 1(3):3136.

[18] idem, hal. 54.

[19] Siagian, Binsar Tampahan., Sensuse, Dana Indra., Pemetaan dan Analisis Knowledge Sharing pada Situs Forum Komunitas Online KASKUS, Jurnal Sistem Informasi MTIUI,Volume 6, Nomor 1, ISSN 1412-8896. Di ambil dari : 
https://123dok.com/document/yjm4k52y-pemetaan-analisis-knowledge-sharing-situskomunitas-online-kaskus.html

[20] Indriyanti, AD dan Pratama, Revaldo, 2015. Perancangan dan Pembuatan Forum Makanan Berbasis Web. Jurnal Manajemen. Volume 04 Nomor 01 di ambil dari: http://ejournal.unesa.ac.id/index.php/jurnalmanajemeninformatika/article/view/1210 9

[21] Widyastuti, Prita, Pemanfaatan Forum Off-Line oleh Komunitas On-Line (Studi Kualitatif Komunitas Pengusaha Muda Jogja KASKUS Regional Yogyakarta), Di ambil dari chromeextension://oemmndcbldboiebfnladdacbdfmadadm/http://eprints.ums.ac.id/20002/1/2 ._HALAMAN_DEPAN.pdf

[22] Putranto, Agus, 2012, Perancangan Forum Diskusi Mobile Online Learning, Binus Journal Publishing, COMTECH Vol. 3 No. 2. Diambil dari : https://journal.binus.ac.id/index.php/comtech/article/view/2315.

[23] Pressman, Roger S, 2010, Rekayasa Perangkat Lunak: Pendekatan Praktisi (Buku Satu), Andi, Yogyakarta. 